\title{
What did we learn from the SARS-CoV-2 vaccine breakthrough infections
}

\author{
Afra Shamnath $^{1}$, Mercy Rophina ${ }^{1,2}$, Bani Jolly ${ }^{1,2}$, Rahul C. Bhoyar ${ }^{1}$, Sridhar Sivasubbu ${ }^{1,2}$, and Vinod Scaria ${ }^{1,2, \#}$ \\ Author affiliations: \\ ${ }^{1}$ CSIR Institute of Genomics \& Integrative Biology [CSIR-IGIB], Mathura Road, Delhi 110025, India \\ ${ }^{2}$ Academy for Scientific and Innovative Research, Human Resource Development Centre Campus, Ghaziabad, Uttar \\ Pradesh, India \\ *Correspondence: Vinod Scaria, vinods@igib.in

\section{Email of authors:} \\ Afra Shamnath - afrashamnath230896@gmail.com \\ Mercy Rophina - mercywilliams1608@gmail.com \\ Bani Jolly- banijolly1995@gmail.com \\ Rahul C. Bhoyar- rc.bhoyar23@gmail.com \\ Sridhar Sivasubbu- $\underline{\text { sridhar@igib.in }}$
}

\begin{abstract}
The unprecedented pace in vaccine research and clinical development have provided a number of COVID-19 vaccines now widely used and many more candidates are currently in clinical development. While vaccination has been picking up, the emergence of variants and the continued spread of COVID-19 in some regions of the world have resulted in vaccine breakthrough infections. The early insights from epidemiological studies as well as genomic surveillance of vaccine breakthrough infections have provided unique and valuable data. Despite the ample paucity of data regarding breakthrough infections due to under-reporting and lack of uniform testing and reporting measures, here we try to navigate the different aspects of SARS-CoV-2 vaccines, breakthrough infections and the various other factors that could influence them.
\end{abstract}

Keywords: SARS-CoV-2, breakthrough infections, vaccines, sieve analysis, variants, healthcare workers, genomics, variants of concern, immune escape

\section{Introduction}

Vaccines have been one of the best armaments mankind has against a variety of infectious agents. This is exemplified by the fact that vaccines have enabled the control of many diseases and even the eradication of a few. While vaccines differ in their efficacy, in rare occasions a pathogen can partially or completely evade the immunity conferred by vaccines in an individual resulting in a vaccine breakthrough infection[1]. Keeping aside the effectiveness of vaccines, which is a major contributing factor[2], it is widely thought that vaccine breakthrough infections could be attributed to pathogens acquiring specific genetic variants[3] as a part of natural evolution. Vaccine breakthrough infections have now been reported for a number of pathogens including Varicella-zoster virus[4], Streptococcus pneumoniae [5] and others. 
With the rapid spread of SARS-CoV-2 across the globe, accelerated research and clinical trials have enabled one of the fastest clinical developments of vaccines in human history. Massive vaccination efforts that ensued in some regions of the world have significantly contributed to reducing the number of new cases. However, a significant number of COVID-19 vaccine breakthrough events have been observed worldwide in recent months. The recent estimates for such events range from $0.04 \%$ to $13 \%$ as per recent studies [6-12]. Despite the numbers and literature reported in this study, it should be noted that these studies are probably an under-estimate since many countries and regions across the globe do not have systematic efforts to document and follow-up vaccine breakthrough infections. Efforts aimed at genomic characterization of vaccine breakthrough infections are also limited[13].

\section{Early estimates of breakthrough infections from clinical trials}

One of the important datasets to assess the incidence of breakthrough infections is the Phase III clinical trial data for vaccines. The data for BNT162b2 (Pfizer-BioNTech mRNA vaccine) suggests that a two-dose administration provides $95 \%$ immunity in age groups above 16 years suggesting a median safety range of over two months for the vaccine in preventing the disease.[14] The vaccine also provides a very low breakthrough incidence of $0.04 \%$ [14] while data for AZD1222/ChAdOx1 nCoV-19 (Covishield) suggests a breakthrough infection rate of $0.2 \%$ to $0.6 \%$ [15]. For mRNA-1273 (Moderna) phase III clinical trials found that $0.1 \%$ of the cohort was positive for the virus in time for the second dose. [16] Phase III clinical trial for BBV152, a whole-virion inactivated SARS-CoV-2 (Covaxin) presented a breakthrough rate of $0.77 \%$ in the cohort, two weeks post-vaccination[17]. Mathematical models would be effective in understanding vaccine effectiveness and post-exposure vaccine variables over time.[18] The wide variability in the incidence of vaccine breakthroughs as evident from clinical trial datasets suggest significant differences in the efficacy of vaccines and possibly a major contributor to vaccine breakthrough infections.

\section{Healthcare workers are potentially at a higher risk for vaccine breakthrough infections}

As frontliners, healthcare workers seem to be at a much higher risk than the general population to develop breakthrough infections[19]. In a prospective cohort study by Nguyen et.al, it was found that HCW were 11 fold more susceptible to infection than the general masses.[20] In many countries, healthcare workers were prioritized for receiving the initial vaccine doses[21] and the early reports provide unique insights into the prevalence and predisposing factors of breakthrough infections in healthcare workers. One of the early studies suggesting the higher risk for healthcare workers has come out of a recent study in US Military Health System beneficiaries[22] which suggested that the majority of the cases of vaccine breakthrough infections were reported in healthcare workers. In a recent report from Israel, 22 out of 4,081 (0.54\%) health care workers had breakthrough infections after being vaccinated with the BNT162b2 vaccine[11]. In a study conducted in California among health care workers, the absolute risk of a breakthrough infection after mRNA-1273 and BNT162b2 vaccination was reported to be $1.19 \%$ at UC San Diego and $0.97 \%$ at the University of California, Los Angeles respectively. [23]

In India, a recent study comprising over 7000 fully vaccinated healthcare workers in a tertiary care centre in South India, reported the incidence of breakthrough infections were as high as $9.6 \%$ [24]. One of the initial studies from Kerala elaborates on the symptomatic breakthrough infection in 6 health care workers[25]. A similar observation of 48 out of 506 health workers testing positive after two rounds of inoculation was observed [26] from Northern India. In addition, a smaller cohort of 325 healthcare workers from North India suggested an incidence of 11.3\% [27] following BBV152 or AZD1222 [ChAdOx1-S] vaccine doses and a study involving 1322 healthcare workers from a tertiary care centre vaccinated with two doses of ChAdOx1/Covishield [28] showed that 8.17\% had breakthrough infections with the majority being young and devoid of any associated comorbidities. Health care workers who had been infected and recovered once with SARS-CoV-2 were found 4.5 times less likely to experience a breakthrough infection post inoculation[27]. 


\section{Pre-existing antibodies and breakthrough infections}

Evidence gleaned from recent breakthrough infection reports suggest that a few individuals possessed neutralising antibodies at the time of infection, indicating that the neutralising antibodies alone may not be sufficient to prevent breakthrough infections and their levels may not be predictive of sterilizing immunity[29]. Reports of the effects of boosting with the ancestral SARS-CoV-2 spike antigen in people who have already been infected with the ancestral virus, have shown that vaccinating individuals with the beta spike antigen resulted in over $10 \%$ boosting in comparison with the ancestral strain, yet at the same time, led to a reduction of the 345 responses to the ancestral and gamma strains.[30] However, in another study, which comprehensively compared the antibody titres of vaccinated individuals (either single or double doses of BNT162b2 vaccine) with and without previous infections, it was observed that antibody titers increased manifold in participants who had been earlier infected with the virus than the participants who had never been infected before. The levels increased 5.2 fold against B.1.1.7, 6.5 fold against B.1.351, 4.3 fold against P.1, and 3.4 fold against original SARS-CoV-2 for the former[31]. A study on a cohort of vaccine breakthroughs following mRNA vaccine suggested the majority of patients with vaccine breakthroughs indeed had anti-spike antibodies[22].

In addition to all the above, there exist studies that explored the association and impact of demographic statuses and other comorbid conditions in antibody levels. For instance, a cross-sectional quality improvement study of elderly in residential care [who received two vaccine doses] was conducted in Pittsburgh and suggested that sex, age and medication, influenced antibody levels. It was also found that antibody levels were comparatively lower in males[32]. A similar cross-sectional study conducted in the United Kingdom amongst healthcare workers and patients with immunodeficiencies explored that neutralisation of Variants of Concern (VoCs)with the E484K was much lower in the participants without any known previous infection of SARS-CoV-2. Markedly, participants who had been inoculated once with either BNT162b2 /AZD1222 and those who had previous infection history had a notable increase in neutralising titres[33] thereby emphasizing the fact that neutralising antibodies act as entities in providing protection against severe infection and hospitalisation. [34]

\section{Variants of Concern and Immune Escape variants}

Despite the unprecedented speed at which the vaccines were available to the public and the much hope it brought, viruses are known to inherently evolve with time[35]. Unlike DNA viruses, RNA viruses mutate alarmingly at much faster rates[36]. In a study by Vilar et.al, mutation rates in the proteome of the virus increased rapidly from December 2019 to July 2020 but seemed to stabilise after July to November 2020 with a modest increment in the mutation rate globally.[37] During the timeline of October-November 2020, the mutation rate in the spike protein was known to be 0.999 [37]. Basic reproduction number for the virus was estimated to be 2.24-3.58[38]. With such rates, extensive mutation analyses were needed to pre-empt the consequences of host immune evasion and vaccine efficacy. Unfortunately, Variants of Concerns (VoCs) and Variant of Interests (VoI)s have emerged and have raised alarms due to its ability to escape neutralising antibodies and evade the host immune responses with increased infectivity and transmissibility worsening the state[39, 40]. On June 15, 2021, the WHO classified the VoCs as Alpha (B.1.1.7), Beta (B.1.315), Gamma (P.1), and Delta (B.1.617.2) based on their associated risk factors including increase in virulence, transmissibility and immune escape[41].

Of recent, newer variants of Delta (AY.1, AY.2, AY.3) have been circulating which was first observed in India[42]. AY.1 and AY.2 variants are characterised by $\mathrm{K} 417 \mathrm{~N}$, one of the mutations noted for immune escape as well as disruption of RBD [Receptor Binding Domain] [43]. A study in Houston, Texas has reported increased vaccine breakthrough $(\mathrm{n}=255)$ with Delta variants in recipients of Moderna mRNA-1273(13\%), Pfizer-BioNTech BNT162b2 (84\%) and J\&J/Janssen JNJ-78436735(2\%)[44]. In a hospital based cohort study from India, vaccine breakthrough with Delta variants in 
recipients of COVISHIELD [ChAdOx1] or COVAXIN [BBV-152] [ $\mathrm{n}=495]$ has also been a cause of concern.[45] In a genomic analysis study of breakthrough infections throughout India by Gupta et.al, states that almost 443 (86.69\%) genomes analysed of the cohort of 677 from seventeen states had evidence of the Delta variant along with Alpha (B.1.1.7), Kappa (B.1.617.1), Delta AY.1 and Delta AY.2.[46] Despite these alarming numbers, fatality rates in this study was reported to be only $0.4 \%$ of the cohort. [46]

The emergence of viral genetic variants in the recent months associated with increased transmissibility, immune escape or both have created interest in understanding their correlates with vaccine efficacy and breakthrough infections[7]. A significant majority of the published breakthrough infections have been caused by variants of concern as evidenced from reports from the United States of America [47], Israel[48] and India [49]. Supplementary Table 1 enlists the comprehensive list of breakthrough infections reported worldwide. With the Delta variant on the rise In a recent report from Washington, USA it was interesting to note that a single mutation W258L, present in the $\mathrm{N}$ terminal domain (NTD) of SARS-CoV-2 antigen supersite was found to be expressed 5.22 fold more in breakthrough samples, thereby suggesting that it is not just the spike mutations in the receptor binding site which are at concern [47]. In contrast, 10 breakthrough cases from Florida were a result of household transmission suggesting that COVID infections may not only be restricted to high risk environments or variants of concern.[50]

Of recent relevance is a variant of concern B.1.617.2 [Delta] which has been associated with the surge in COVID-19 cases in India and also in many countries around the world. In a study by Mlcochova et al., reviewing more than hundred health care workers with vaccine breakthrough infections in India, the B.1.617.2 variant was associated with greater respiratory viral loads ( $\mathrm{Ct}$ value of 16.5 versus 19 ) and transmissibility (mean cluster size 1.1 versus 3.3 $\mathrm{p}=0.03$ ) with respect to B.1.1.7 (Alpha) or (Kappa) B.1.617.1[51]. When analysing sensitivity to vaccine-elicited antibodies in the same study, there was also an eight fold reduction when compared to the wild type Wuhan-1 bearing D614G.[51]

A study by Garcia-Beltran et al. had analysed the vaccine neutralisation potency of BNT162b2 or mRNA-1273 in recipients that had received either one or two doses against ten pseudo viral strains of SARS-CoV-2. Noticeably E484K, $\mathrm{K} 417 \mathrm{~N} / \mathrm{T}$, and N501Y, were highly resistant to neutralization. Fewer mutations may also escape vaccines as inferred from the observation that the diminution of neutralisation of B.1.351 (beta) were akin to SARS-CoV and WIV1-CoV (bat). For SARS-CoV, neutralisation was 43.8-fold for BNT162b2 and 33.5-fold for mRNA-1273. For bat derived, it was 44.3 fold for BNT162b2 and 26.5-fold for mRNA-1273. [52]

Specific mutations, like the spike protein mutation E484K has also been reported to have potential associations with vaccine breakthrough infections from many other countries $[7,53]$ E484K mutation is also of relevance as it occurs in different lineages and has already been found in the B.1.351 (Beta) and P.1 (Gamma) lineages. A recent study suggests specific spike protein deletions are associated with many emerging lineages across the globe, apart from a case of breakthrough infection characterized by the 156-164 deletion in the antigenic supersite.[54]

\section{Sieve Analysis to identify mutations associated with breakthrough infections}

Clinical trials for SARS-CoV-2 vaccines have mostly been reported to have produced noteworthy responses in providing protective immunity. Immune responses in vaccine breakthrough infections also have a corollary at the genetic level. One method of understanding vaccine effectiveness vis-a-vis the genotypic correlates has been through a sieve analysis[55], which can provide insights on the efficacy of vaccines in conferring protection against emerging viral variants. The pioneering study on sieve analysis of SARS-CoV-2 suggests that the virus possessing a much lower rate of mutation compared to most other RNA viruses could mean that clinically developed vaccines were efficacious against most globally circulating variants [55]. In favour of the above stated findings, a comprehensive comparative analysis of 
360,382 global genome sequences exhibited an average mutation rate of 9 amino acid changes across the proteome and 2 amino acid changes in the vaccine targeted spike protein region [55]. In another analysis in the same study looking into the sieve effects in a cohort of vaccine recipients and placebo cohort, hamming distances with respect to count revealed that the viruses present in the inoculated group were significantly distant from the sequence of the vaccinated group[55]. Thus a combination of both sieve analysis as well as genomic surveillance is momentous for better characterisation and understanding of viral evolution and its impact on vaccine efficacy.

\section{Immune mechanisms governing disease and breakthroughs}

Apart from the B cell responses, which have been extensively studied, $\mathrm{T}$ cell responses to any vaccine candidates are usually evaluated by quantifying the cytokine expression (Interferon- $\gamma$ - IFN- $\gamma$ in most cases). While not much is known about the $\mathrm{T}$ cell immunity in breakthrough infections, recent reports have elaborated the vaccine induced generation of antigen specific $\mathrm{T}$ cells against SARS-CoV-2[56]. Assessment of $\mathrm{T}$ cell responses induced by mRNA vaccines were not found to be strongly triggered [57-62]. In a study conducted amongst healthy immunocompetent individuals there was a numeric reduction in S1-, S2-, and S-reactive CD4 and CD8 T-cell frequencies for the first inoculation. Post second inoculation, the vaccine numbers had reduced to pre vaccine proportions [58].Quantification of $\mathrm{T}$ cell immune response after first inoculation of Pfizer/BioNTech BNT162b2 vaccine in a cohort of healthcare workers showed evident results after ten days.[59] At least one recent study suggests genetic mutations in Delta (B.1.617.2) could disrupt an immunodominant T cell epitope[60]. The clinical implications of which are not known, also possibly due to the fact that the T cell epitopes are also influenced by the HLA restriction which is difficult to delineate. On the flip side, investigating more on breakthrough infections would permit detecting unique imprints related to antibody-mediated Fc effector tasks. This follows the same for T-cell responses associated with HLA-linked polymorphisms. [55] In a study by Niesen et al. with a cohort of 26 breakthrough infection cases, T cell epitopes were found to be much less mutated than B cell epitopes (2.3-fold). This could imply that breakthrough mutations are more likely to occur at the antibody binding receptors and that counting on $\mathrm{T}$ cell immunity would provide better protection against circulating variants.[61]

\section{Severity and Outcomes}

The vaccines currently being administered are mostly designed to prevent lower respiratory tract infections $[14,16$, 62-64] and therefore a clear understanding of the mucosal immune system needs to be taken into account [64]. Reports of symptomatic breakthrough infections have suggested most of the infections had mild to moderate symptoms[65]. However, according to data released by the CDC on June 7, 2021, the number of hospitalized and fatal COVID-19 vaccine breakthrough cases were only 5,186 patients in a total of over 157 million people fully vaccinated [66]. Data from Public Health England, has suggested that the immunisations have averted over 14,000 deaths and around 42,000 hospitalisations.[67] Israel observed that a small subset of vaccinees who had received BNT162b2 mRNA vaccine had developed infections within 12-28 days and had their viral load drastically reduced by over 4-fold after the first inoculation.[68] Even though clinical data regarding vaccine effectiveness is limited, studies have shown $70-90 \%$ decrease in new cases post inoculation and a lower severity of infections[65] . In cases that report vaccine breakthrough, there are studies which account for decreased viral load for recipients of BNT162b2 vaccine.[69]

Factors including comorbid conditions like Multiple Myeloma and age have been reported as potential predisposing factors of disease severity and antibody responses [70]although contrasting evidence of vaccine breakthroughs reported following mRNA-1273 and BNT162b2 vaccines recently shows it could occur across a wide age-group of individuals with no significant comorbidity or immunosuppression [22].

\section{Conclusion}


Immunisation is one of the most cost effective and essential means to ensure public health protection from any vaccine preventable disease[71]. Data regarding the duration of protection of vaccines vary suggesting that amongst the immunised strata the effect of the vaccine provided is heterogeneous[72]. It is therefore imperative that more studies need to be conducted to further understand vaccine derived and natural immunity. Such studies also may offer better insights into vaccine booster timings and breakthrough infections [34]. Despite the efforts to vaccinate everybody globally against COVID-19 and many other infectious diseases, it is disheartening that vaccine inequities prevail. [73]With the emergence of new variants, it is crucial to re-emphasise that nobody is safe until everyone is safe.

Analysing the genetic diversity of the virus within hosts that have already been infected have provided slight acumen to the upcoming strains as well as the transmission of the viruses at hand[74, 75]. Viral genome sequencing has helped in perceiving the extent of transmission by reconstructing motifs to monitor its spread. However, one flaw may be the fact that there isn't enough consensus to determine "who infected whom." Breakthrough infections with SARS-CoV-2 variants thus have serious implications and pose a serious threat to vaccine efficacy.

Breakthrough infections, while rare entities, have not been uncommon due to the large number of individuals vaccinated and a number of emerging variants of concern. Nevertheless the favourable outcomes in such cases have re-emphasised the utility of vaccines in controlling the wayward spread of infections as well as reducing mortality and morbidity due to COVID-19. Functional characterisation as well as genome sequencing is the need of the hour as it would provide better insights into breakthrough infections. More than surveillance, public health communication and awareness is also necessary for effective management of breakthrough infections. It would be misleading to say that breakthrough infections were a result of vaccine ineffectiveness. Thus studying post exposure effects of vaccines have immense importance and utility in curbing future outbreaks and epidemics.

\section{Author Contributions:}

AS, VS, MR contributed in writing. VS conceptualised the manuscript. BJ, RB and SS improvised the manuscript with constructive suggestions and comments. All authors approved the final manuscript.

\section{Acknowledgements}

Author BJ acknowledges the research fellowships from CSIR India. Funding agencies had no role in the preparation of manuscript or decision to publish.

\section{Conflict of Interest}

The authors declare that there are no conflicts of interest.

\section{References}

1. The immune response and immune evasion characteristics in SARS-CoV, MERS-CoV, and SARS-CoV-2: Vaccine design strategies, Int. Immunopharmacol., Elsevier 92, 107051.

2. Gallagher, T., and Lipsitch, M. [2019] Post-Exposure Effects of Vaccines on Infectious Diseases, medRxiv, Cold Spring Harbor Laboratory Press 19001396.

3. Jolly, B., Rophina, M., Shamnath, A., Imran, M., Bhoyar, R. C., Divakar, M. K., Rani, P. R., Ranjan, G., Sehgal, P., Chandrasekhar, P., Afsar, S., Vijaya Lakshmi, J., Surekha, A., Sivasubbu, S., and Scaria, V. Genetic epidemiology of variants associated with immune escape from global SARS-CoV-2 genomes.

4. Analysis of varicella vaccine breakthrough rates: implications for the effectiveness of immunisation programmes, Vaccine, Elsevier 18, 2775-2778.

5. Adebanjo, T. A., Pondo, T., Yankey, D., Hill, H. A., Gierke, R., Apostol, M., Barnes, M., Petit, S., Farley, M., Harrison, L. H., Holtzman, C., Baumbach, J., Bennett, N., McGuire, S., Thomas, A., Schaffner, W., Beall, B., Whitney, C. G., and Pilishvili, T. [2020] Pneumococcal Conjugate Vaccine Breakthrough Infections: 2001-2016, Pediatrics, American 
Academy of Pediatrics 145.

6. Shah, J., Samson, P., Pradhan, N. M. S., Maharjan, S., Shrestha, A., Shah, J., Shah, J., and Sarala, K. C. [2021]

Breakthrough infection after COVID-19 vaccination: A threat for Nepal due to SARS-CoV-2 variants circulating in 2nd wave ravaging India, JPAHS 8, e1-e11.

7. Hacisuleyman, E., Hale, C., Saito, Y., Blachere, N. E., Bergh, M., Conlon, E. G., Schaefer-Babajew, D. J., DaSilva, J., Muecksch, F., Gaebler, C., Lifton, R., Nussenzweig, M. C., Hatziioannou, T., Bieniasz, P. D., and Darnell, R. B. Vaccine Breakthrough Infections with SARS-CoV-2 Variants, N. Engl. J. Med. 384, 2212-2218.

8. Teran, R. A., Walblay, K. A., Shane, E. L., Xydis, S., Gretsch, S., Gagner, A., Samala, U., Choi, H., Zelinski, C., and Black, S. R. [2021] Postvaccination SARS-CoV-2 Infections Among Skilled Nursing Facility Residents and Staff Members - Chicago, Illinois, December 2020-March 2021, MMWR. Morbidity and Mortality Weekly Report.

9. Jacobson, K. B., Pinsky, B. A., Montez Rath, M. E., Wang, H., Miller, J. A., Skhiri, M., Shepard, J., Mathew, R., Lee, G., Bohman, B., Parsonnet, J., and Holubar, M. [2021] Post-vaccination SARS-CoV-2 infections and incidence of the B.1.427/B.1.429 variant among healthcare personnel at a northern California academic medical center, medRxiv, Cold Spring Harbor Laboratory Press 2021.04.14.21255431.

10. Chaofeng, Ma, Songtao, Xu, Yecheng, Yao, Pengbo, Yu, You, Xu, Rui, Wu, Hailong, Chen, Xiaoping, and Dong. Mild Breakthrough Infection in a Healthcare Professional Working in the Isolation Area of a Hospital Designated for Treating COVID-19 Patients - Shaanxi Province, China, March, 2021, China CDC Weekly 1-4.

11. Amit, S., Beni, S. A., Biber, A., Grinberg, A., Leshem, E., and Regev-Yochay, G. [2021] Postvaccination COVID-19 among Healthcare Workers, Israel, Emerg. Infect. Dis. 27, 1220-1222.

12. Philomina, B., Jolly, B., John, N., Bhoyar, R. C., Majeed, N., Senthivel, V., C., F., Rophina, M., Vasudevan, B., Imran, M., Viswanathan, P., Arvinden, Joseph, A., Divakar, M. K., Nair, P. R., Shamnath, A., Kumar, P. J., Jain, A., Geetha, P., Bajaj, A., Mathew, S., Gupta, V., Agrawal, S. J., Radhakrishnan, C., Scaria, V., and Sivasubbu, S. [2021, May 10] Genomic survey of SARS-CoV-2 vaccine breakthrough infections in healthcare workers from Kerala, India.

13. Siegel, M. [2021] Notes from the Field: SARS-CoV-2 Transmission Associated with High School Football Team Members - Florida, September-October 2020, MMWR Morb. Mortal. Wkly. Rep. 70.

14. Polack, F. P., Thomas, S. J., Kitchin, N., Absalon, J., Gurtman, A., Lockhart, S., Perez, J. L., Pérez Marc, G., Moreira, E. D., Zerbini, C., Bailey, R., Swanson, K. A., Roychoudhury, S., Koury, K., Li, P., Kalina, W. V., Cooper, D., Frenck, R. W., Jr, Hammitt, L. L., Türeci, Ö., Nell, H., Schaefer, A., Ünal, S., Tresnan, D. B., Mather, S., Dormitzer, P. R., Şahin, U., Jansen, K. U., Gruber, W. C., and C4591001 Clinical Trial Group. [2020] Safety and Efficacy of the BNT162b2 mRNA Covid-19 Vaccine, N. Engl. J. Med. 383, 2603-2615.

15. Safety and efficacy of the ChAdOx1 nCoV-19 vaccine [AZD1222] against SARS-CoV-2: an interim analysis of four randomised controlled trials in Brazil, South Africa, and the UK, Lancet, Elsevier 397, 99-111.

16. Baden, L. R., El Sahly, H. M., Essink, B., Kotloff, K., Frey, S., Novak, R., Diemert, D., Spector, S. A., Rouphael, N., Creech, C. B., McGettigan, J., Khetan, S., Segall, N., Solis, J., Brosz, A., Fierro, C., Schwartz, H., Neuzil, K., Corey, L., Gilbert, P., Janes, H., Follmann, D., Marovich, M., Mascola, J., Polakowski, L., Ledgerwood, J., Graham, B. S., Bennett, H., Pajon, R., Knightly, C., Leav, B., Deng, W., Zhou, H., Han, S., Ivarsson, M., Miller, J., Zaks, T., and COVE Study Group. [2021] Efficacy and Safety of the mRNA-1273 SARS-CoV-2 Vaccine, N. Engl. J. Med. 384, 403-416.

17. Ella, R., Reddy, S., Blackwelder, W., Potdar, V., Yadav, P., Sarangi, V., Aileni, V. K., Kanungo, S., Rai, S., Reddy, P., Verma, S., Singh, C., Redkar, S., Mohapatra, S., Pandey, A., Ranganadin, P., Gumashta, R., Multani, M., Mohammad, S., Bhatt, P., Kumari, L., Sapkal, G., Gupta, N., Abraham, P., Panda, S., Prasad, S., Bhargava, B., Ella, K., Vadrevu, K. M., and the COVAXIN Study Group. [2021, July 2] Efficacy, safety, and lot to lot immunogenicity of an inactivated SARS-CoV-2 vaccine [BBV152]: a, double-blind, randomised, controlled phase 3 trial, bioRxiv, medRxiv.

18. Ziv, E., Daley, C. L., and Blower, S. [2004] Potential public health impact of new tuberculosis vaccines, Emerg. Infect. Dis. 10, 1529-1535.

19. [2020] Risk of COVID-19 among front-line health-care workers and the general community: a prospective cohort study, The Lancet Public Health, Elsevier 5, e475-e483.

20. Nguyen, L. H., Drew, D. A., Joshi, A. D., Guo, C.-G., Ma, W., Mehta, R. S., Sikavi, D. R., Lo, C.-H., Kwon, S., Song, M., Mucci, L. A., Stampfer, M. J., Willett, W. C., Eliassen, A. H., Hart, J. E., Chavarro, J. E., Rich-Edwards, J. W., Davies, R., Capdevila, J., Lee, K. A., Lochlainn, M. N., Varsavsky, T., Graham, M. S., Sudre, C. H., Cardoso, M. J., Wolf, J., Ourselin, S., Steves, C. J., Spector, T. D., and Chan, A. T. [2020] Risk of COVID-19 among frontline healthcare workers and the general community: a prospective cohort study, medRxiv.

21. Russell, F. M., and Greenwood, B. [2021] Who should be prioritised for COVID-19 vaccination?, Hum. Vaccin. Immunother. 17, 1317-1321.

22. Pollett, S. D., Richard, S. A., Fries, A. C., Simons, M. P., Mende, K., Lalani, T., Lee, T., Chi, S., Mody, R., Madar, C., Ganesan, A., Larson, D. T., Colombo, C. J., Colombo, R., Samuels, E. C., Broder, C. C., Laing, E. D., Smith, D. R., Tribble, 
D., Agan, B. K., and Burgess, T. H. [2021] The SARS-CoV-2 mRNA vaccine breakthrough infection phenotype includes significant symptoms, live virus shedding, and viral genetic diversity, Clin. Infect. Dis.

23. Keehner, J., Horton, L. E., Pfeffer, M. A., Longhurst, C. A., Schooley, R. T., Currier, J. S., Abeles, S. R., and Torriani, F. J. [2021] SARS-CoV-2 Infection after Vaccination in Health Care Workers in California, N. Engl. J. Med. 384, 1774-1775.

24. Victor, P. J., Prasad Mathews, K., Paul, H., Murugesan, M., and Mammen, J. J. [2021] Protective Effect of COVID-19 Vaccine Among Health Care Workers During the Second Wave of the pandemic in India, Mayo Clinic Proceedings.

25. Genomic survey of SARS-CoV-2 vaccine breakthrough infections in healthcare workers from Kerala, India, J. Infect., W.B. Saunders.

26. Blachere, N. E., Hacisuleyman, E., and Darnell, R. B. [2021, June 2] Vaccine breakthrough infections with SARS-CoV-2 variants. Reply, N. Engl. J. Med.

27. Sharma, P., Mishra, S., Basu, S., Tanwar, N., and Kumar, R. [2021] Breakthrough infection with SARS-CoV-2 and its predictors among healthcare workers in a medical college and hospital complex in Delhi, India, medRxiv, Cold Spring Harbor Laboratory Press 2021.06.07.21258447.

28. Niyas, V. K. M., and Arjun, R. [2021] Correspondence: Breakthrough COVID-19 Infections among Health Care Workers after Two Doses of ChAdOx1 nCoV-19 Vaccine, QJM, Oxford University Press.

29. Bradley, B. T., Bryan, A., Fink, S. L., Goecker, E. A., Roychoudhury, P., Huang, M.-L., Zhu, H., Chaudhary, A., Madarampalli, B., Lu, J. Y. C., Strand, K., Whimbey, E., Bryson-Cahn, C., Schippers, A., Mani, N. S., Pepper, G., Jerome, K. R., Morishima, C., Coombs, R. W., Wener, M., Cohen, S., and Greninger, A. L. [2021] Anti-SARS-CoV-2 antibody levels are concordant across multiple platforms but are not fully predictive of sterilizing immunity, medRxiv, Cold Spring Harbor Laboratory Press 2021.04.26.21256118.

30. Cromer, D., Steain, M., Reynaldi, A., Schlub, T. E., Wheatley, A. K., Juno, J. A., Kent, S. J., Triccas, J. A., Khoury, D. S., and Davenport, M. P. SARS-CoV-2 variants: levels of neutralisation required for protective immunity.

31. Leier, H. C., Bates, T. A., Lyski, Z. L., McBride, S. K., X Lee, D., Coulter, F. J., Goodman, J. R., Lu, Z., Curlin, M. E., Messer, W. B., and Tafesse, F. G. [2021] Previously infected vaccinees broadly neutralize SARS-CoV-2 variants, medRxiv.

32. Nace, D. A., Kip, K. E., Peck Palmer, O. M., Shurin, M. R., Mulvey, K., Crandall, M., Kane, A. L., Lukanski, A., Kip, P. L., and Wells, A. L. [2021] Antibody Responses in Elderly Residential Care Persons following COVID-19 mRNA Vaccination, medRxiv, Cold Spring Harbor Laboratory Press 2021.04.07.21254925.

33. Nadesalingam, A., Cantoni, D., Wells, D. A., Aguinam, E. T., Ferrari, M., Smith, P., Chan, A., Carnell, G., Ohlendorf, L., Einhauser, S., Wagner, R., Temperton, N., Castillo-Olivares, J., Baxendale, H., Heeney, J. L., and the HICC consortium. [2021] Breadth of neutralising antibody responses to SARS-CoV-2 variants of concern is augmented by vaccination following prior infection: studies in UK healthcare workers and immunodeficient patients, medRxiv, Cold Spring Harbor Laboratory Press 2021.06.03.21257901.

34. Cohen, J. A., Stuart, R. M., Núñez, R. C., Wagner, B., Chang, S., Rosenfeld, K., Kerr, C. C., Famulare, M., and Klein, D. J. [2021] Mechanistic modeling of SARS-CoV-2 immune memory, variants, and vaccines, medRxiv, Cold Spring Harbor Laboratory Press 2021.05.31.21258018.

35. Villarreal, L. P. [2008] Evolution of Viruses. In Encyclopedia of Virology, pp 174-184, Elsevier.

36. Duffy, S. [2018] Why are RNA virus mutation rates so damn high?, PLoS Biol., Public Library of Science 16, e3000003.

37. Vilar, S., and Isom, D. G. [2021] One Year of SARS-CoV-2: How Much Has the Virus Changed?, Biology 10.

38. Pathan, R. K., Biswas, M., and Khandaker, M. U. [2020] Time series prediction of COVID-19 by mutation rate analysis using recurrent neural network-based LSTM model, Chaos Solitons Fractals 138, 110018.

39. Hoffmann, M., Arora, P., Groß, R., Seidel, A., Hörnich, B. F., Hahn, A. S., Krüger, N., Graichen, L., Hofmann-Winkler, H., Kempf, A., Winkler, M. S., Schulz, S., Jäck, H.-M., Jahrsdörfer, B., Schrezenmeier, H., Müller, M., Kleger, A., Münch, J., and Pöhlmann, S. [2021] SARS-CoV-2 variants B.1.351 and P.1 escape from neutralizing antibodies, Cell 184, 2384-2393.e12.

40. Cele, S., Gazy, I., Jackson, L., Hwa, S.-H., Tegally, H., Lustig, G., Giandhari, J., Pillay, S., Wilkinson, E., Naidoo, Y., Karim, F., Ganga, Y., Khan, K., Bernstein, M., Balazs, A. B., Gosnell, B. I., Hanekom, W., Moosa, M.-Y. S., Lessells, R. J., de Oliveira, T., and Sigal, A. [2021] Escape of SARS-CoV-2 501Y.V2 from neutralization by convalescent plasma, Nature, Nature Publishing Group 593, 142-146.

41. Tracking SARS-CoV-2 variants.

42. Cherian, S., Potdar, V., Jadhav, S., Yadav, P., Gupta, N., Das, M., Rakshit, P., Singh, S., Abraham, P., Panda, S., and NIC team. [2021, May 3] Convergent evolution of SARS-CoV-2 spike mutations, L452R, E484Q and P681R, in the second wave of COVID-19 in Maharashtra, India, bioRxiv.

43. Wang, R., Chen, J., Gao, K., and Wei, G.-W. [2021] Vaccine-escape and fast-growing mutations in the United 
Kingdom, the United States, Singapore, Spain, India, and other COVID-19-devastated countries, Genomics 113, 2158-2170.

44. Musser, J. M., Christensen, P. A., Olsen, R. J., Long, S. W., Subedi, S., Davis, J. J., Hodjat, P., Walley, D. R., Kinskey, J. C., and Gollihar, J. D. Delta variants of SARS-CoV-2 cause significantly increased vaccine breakthrough COVID-19 cases in Houston, Texas.

45. Jagadeesh Kumar, V., Sowpati, D. T., Munigela, A., Banu, S., Siva, A. B., Sasikala, M., Nutalapati, C., Kulkarni, A., Mukherjee, P., Zaveri, L., CCMB COVID-19 Team, AIG Hospitals COVID-19 Vaccine study Team, Tallapaka, K. B., and Nageshwar Reddy, D. [2021] Clinical outcomes in vaccinated individuals hospitalized with Delta variant of SARS-CoV-2, medRxiv, Cold Spring Harbor Laboratory Press 2021.07.13.21260417.

46. Gupta, N., Kaur, H., Yadav, P., Mukhopadhyay, L., Sahay, R. R., Kumar, A., Nyayanit, D. A., Shete, A. M., Patil, S., Majumdar, T., Rana, S., Gupta, S., Narayan, J., Vijay, N., Barde, P., Natrajan, G., Amurtha Kumari, B., Kumari, M. P., Biswas, D., Iravane, J., Raut, S., Dutta, S., Devi, S., Barua, P., Gupta, P., Borkakoty, B., Kalita, D., Dhingra, K., Fomda, B., Joshi, Y., Goyal, K., John, R., Ashok, Dhodapkar, R., Pandit, P., Devi, S., Dudhmal, M., Kinariwala, D., Khandelwal, N., Tiwari, Y. K., Khatri, P. K., Gupta, A., Khatri, H., Malhotra, B., Nagasundaram, M., Dar, L., Sheikh, N., Aggarwal, N., and Abraham, P. [2021] Clinical characterization and Genomic analysis of COVID-19 breakthrough infections during second wave in different states of India, medRxiv, Cold Spring Harbor Laboratory Press 2021.07.13.21260273.

47. McEwen, A. E., Cohen, S., Bryson-Cahn, C., Liu, C., Pergam, S. A., Lynch, J., Schippers, A., Strand, K., Whimbey, E., Mani, N. S., Zelikoff, A. J., Makarewicz, V. A., Brown, E. R., Mohamed Bakhash, S. A., Baker, N. R., Castor, J., Livingston, R. J., Huang, M.-L., Jerome, K. R., Greninger, A. L., and Roychoudhury, P. [2021] Variants of concern are overrepresented among post-vaccination breakthrough infections of SARS-CoV-2 in Washington State, medRxiv, Cold Spring Harbor Laboratory Press 2021.05.23.21257679.

48. Kustin, T., Harel, N., Finkel, U., Perchik, S., Harari, S., Tahor, M., Caspi, I., Levy, R., Leschinsky, M., Dror, S. K., Bergerzon, G., Gadban, H., Gadban, F., Eliassian, E., Shimron, O., Saleh, L., Ben-Zvi, H., Amichay, D., Ben-Dor, A., Sagas, D., Strauss, M., Avni, Y. S., Huppert, A., Kepten, E., Balicer, R. D., Nezer, D., Ben-Shachar, S., and Stern, A. [2021] Evidence for increased breakthrough rates of SARS-CoV-2 variants of concern in BNT162b2 mRNA vaccinated individuals, medRxiv, Cold Spring Harbor Laboratory Press 2021.04.06.21254882.

49. Dhar, M. S., Marwal, R., Radhakrishnan, V. S., Ponnusamy, K., Jolly, B., Bhoyar, R. C., Fatihi, S., Datta, M., Singh, P., Sharma, U., Ujjainia, R., Naushin, S., Bhateja, N., Divakar, M. K., Sardana, V., Singh, M. K., Imran, M., Senthivel, V., Maurya, R., Jha, N., Mehta, P., Rophina, M., Arvinden, V. R., Chaudhary, U., Thukral, L., Pandey, R., Dash, D., Faruq, M., Lall, H., Gogia, H., Madan, P., Kulkarni, S., Chauhan, H., Sengupta, S., Kabra, S., The Indian SARS-CoV-2 Genomics Consortium [INSACOG], Singh, S. K., Agrawal, A., and Rakshit, P. [2021] Genomic characterization and Epidemiology of an emerging SARS-CoV-2 variant in Delhi, India, medRxiv, Cold Spring Harbor Laboratory Press 2021.06.02.21258076.

50. Magalis, B. R., Mavian, C., Tagliamonte, M., Rich, S. N., Cash, M., Riva, A., Loeb, J. C., Norris, M., Amador, D. M., Zhang, Y., Shapiro, J., Starostik, P., Marini, S., Myers, P., Ostrov, D., Lednicky, J. A., Glenn Morris, J., Lauzardo, M., and Salemi, M. [2021] SARS-CoV-2 infection of BNT162b2 [mRNA]-vaccinated individuals is not restricted to variants of concern or high-risk exposure environments, medRxiv, Cold Spring Harbor Laboratory Press 2021.05.19.21257237.

51. Mlcochova, P., Kemp, S., Dhar, M. S., Papa, G., Meng, B., Mishra, S., Whittaker, C., Mellan, T., Ferreira, I., Datir, R., Collier, D. A., Singh, S., Pandey, R., Marwal, R., Datta, M., Sengupta, S., Ponnusamy, K., Radhakrishnan, V. S., Abdullahi, A., Goonawardne, N., Brown, J., Charles, O., Chattopadhyay, P., Devi, P., Caputo, D., Peacock, T., Wattal, C., Goel, N., Vaishya, R., Agarwal, M., Lee, o. H., Barcla, W. S., Bhatt, S., Flaxman, S., James, L., Rakshit, P., Agrawal, A., The Indian SARS-CoV-2 Genomics Consortium [INSACOG], CITIID-NIHR BioResource COVID-19 Collaboration, Antranik Mavousian, and Gupta1, R. K. [2021, June 22] SARS-CoV-2 B.1.617.2 Delta variant emergence and vaccine breakthrough, Research Square, Research Square.

52. Multiple SARS-CoV-2 variants escape neutralization by vaccine-induced humoral immunity, Cell, Cell Press 184, 2372-2383.e9.

53. Ulhaq, Z. S., Soraya, G. V., and Indriana, K. [2021] Breakthrough COVID-19 case after full-dose administration of CoronaVac vaccine, Indian J. Med. Microbiol.

54. Venkatakrishnan, A. J., Anand, P., Lenehan, P., Ghosh, P., Suratekar, R., Siroha, A., Chowdhury, D. R., O’Horo, J. C., Yao, J. D., Pritt, B. S., Norgan, A., Hurt, R. T., Badley, A. D., Halamka, J. D., and Soundararajan, V. [2021] Antigenic minimalism of SARS-CoV-2 is linked to surges in COVID-19 community transmission and vaccine breakthrough infections, medRxiv, Cold Spring Harbor Laboratory Press 2021.05.23.21257668.

55. Rolland, M., and Gilbert, P. B. [2021] Sieve analysis to understand how SARS-CoV-2 diversity can impact vaccine protection, PLoS Pathog., Public Library of Science 17, e1009406. 
56. Ewer, K. J., Barrett, J. R., Belij-Rammerstorfer, S., Sharpe, H., Makinson, R., Morter, R., Flaxman, A., Wright, D., Bellamy, D., Bittaye, M., Dold, C., Provine, N. M., Aboagye, J., Fowler, J., Silk, S. E., Alderson, J., Aley, P. K., Angus, B., Berrie, E., Bibi, S., Cicconi, P., Clutterbuck, E. A., Chelysheva, I., Folegatti, P. M., Fuskova, M., Green, C. M., Jenkin, D., Kerridge, S., Lawrie, A., Minassian, A. M., Moore, M., Mujadidi, Y., Plested, E., Poulton, I., Ramasamy, M. N., Robinson, H., Song, R., Snape, M. D., Tarrant, R., Voysey, M., Watson, M. E. E., Douglas, A. D., Hill, A. V. S., Gilbert, S. C., Pollard, A. J., and Lambe, T. [2020] T cell and antibody responses induced by a single dose of ChAdOx1 nCoV-19 [AZD1222] vaccine in a phase 1/2 clinical trial, Nat. Med., Nature Publishing Group 27, 270-278.

57. Klasse, P. J., Nixon, D. F., and Moore, J. P. [2021] Immunogenicity of clinically relevant SARS-CoV-2 vaccines in nonhuman primates and humans, Sci Adv 7.

58. Sindhi, R., Ashokkumar, C., Spishock, B., Saunders, M., Mabasa, A., Sethi, P., Reddy, A., and Nibhanupudy, B. T-cell and antibody immunity after COVID-19 mRNA vaccines in healthy and immunocompromised subjects-An exploratory study, medRxiv, Cold Spring Harbor Laboratory Press 2021.05.21.21257442.

59. [2021] Early T cell and binding antibody responses are associated with COVID-19 RNA vaccine efficacy onset, Med, Cell Press 2, 682-688.e4.

60. Mahajan, S., Kode, V., Bhojak, K., Karunakaran, C., Lee, K., Manoharan, M., Ramesh, A., Sudheendra, H. V., Srivastava, A., Sathian, R., Khan, T., Kumar, P., Gupta, R., Chakraborty, P., and Chaudhuri, A. [2021] Immunodominant T-cell epitopes from the SARS-CoV-2 spike antigen reveal robust pre-existing T-cell immunity in unexposed individuals, Sci. Rep., Nature Publishing Group 11, 1-14.

61. Niesen, M., Anand, P., Silvert, E., Suratekar, R., Pawlowski, C., Ghosh, P., Lenehan, P., Hughes, T., Zemmour, D., OHoro, J. C., Yao, J. D., Pritt, B. S., Norgan, A., Hurt, R. T., Badley, A. D., Venkatakrishnan, A. J., and Soundararajan, V. COVID-19 vaccines dampen genomic diversity of SARS-CoV-2: Unvaccinated patients exhibit more antigenic mutational variance.

62. Sadoff, J., Le Gars, M., Shukarev, G., Heerwegh, D., Truyers, C., de Groot, A. M., Stoop, J., Tete, S., Van Damme, W., Leroux-Roels, I., Berghmans, P.-J., Kimmel, M., Van Damme, P., de Hoon, J., Smith, W., Stephenson, K. E., De Rosa, S. C., Cohen, K. W., McElrath, M. J., Cormier, E., Scheper, G., Barouch, D. H., Hendriks, J., Struyf, F., Douoguih, M., Van Hoof, J., and Schuitemaker, H. [2021] Interim Results of a Phase 1-2a Trial of Ad26.COV2.S Covid-19 Vaccine, N. Engl. J. Med. 384, 1824-1835.

63. Voysey, M., Costa Clemens, S. A., Madhi, S. A., Weckx, L. Y., Folegatti, P. M., Aley, P. K., Angus, B., Baillie, V. L., Barnabas, S. L., Bhorat, Q. E., Bibi, S., Briner, C., Cicconi, P., Clutterbuck, E. A., Collins, A. M., Cutland, C. L., Darton, T. C., Dheda, K., Dold, C., Duncan, C. J. A., Emary, K. R. W., Ewer, K. J., Flaxman, A., Fairlie, L., Faust, S. N., Feng, S., Ferreira, D. M., Finn, A., Galiza, E., Goodman, A. L., Green, C. M., Green, C. A., Greenland, M., Hill, C., Hill, H. C., Hirsch, I., Izu, A., Jenkin, D., Joe, C. C. D., Kerridge, S., Koen, A., Kwatra, G., Lazarus, R., Libri, V., Lillie, P. J., Marchevsky, N. G., Marshall, R. P., Mendes, A. V. A., Milan, E. P., Minassian, A. M., McGregor, A., Mujadidi, Y. F., Nana, A., Padayachee, S. D., Phillips, D. J., Pittella, A., Plested, E., Pollock, K. M., Ramasamy, M. N., Ritchie, A. J., Robinson, H., Schwarzbold, A. V., Smith, A., Song, R., Snape, M. D., Sprinz, E., Sutherland, R. K., Thomson, E. C., Török, M. E., Toshner, M., Turner, D. P. J., Vekemans, J., Villafana, T. L., White, T., Williams, C. J., Douglas, A. D., Hill, A. V. S., Lambe, T., Gilbert, S. C., Pollard, A. J., and Oxford COVID Vaccine Trial Group. [2021] Single-dose administration and the influence of the timing of the booster dose on immunogenicity and efficacy of ChAdOx1 nCoV-19 [AZD1222] vaccine: a pooled analysis of four randomised trials, Lancet 397, 881-891.

64. Schieffelin, J. S., Norton, E. B., and Kolls, J. K. [2021] What should define a SARS-CoV-2 "breakthrough" infection?, J. Clin. Invest. 131.

65. Breakthrough COVID19 infections after vaccinations in healthcare and other workers in a chronic care medical facility in New Delhi, India, Diabetes \& Metabolic Syndrome: Clinical Research \& Reviews, Elsevier 15, 1007-1008.

66. COVID-19 Breakthrough Case Investigations and Reporting.

67. Bernal, J. L., Andrews, N., Gower, C., Gallagher, E., Simmons, R., Thelwall, S., Stowe, J., Tessier, E., Groves, N., Dabrera, G., Myers, R., Campbell, C., Amirthalingam, G., Edmunds, M., Zambon, M., Brown, K., Hopkins, S., Chand, M., and Ramsay, M. [2021] Effectiveness of COVID-19 vaccines against the B.1.617.2 variant, medRxiv, Cold Spring Harbor Laboratory Press 2021.05.22.21257658.

68. Levine-Tiefenbrun, M., Yelin, I., Katz, R., Herzel, E., Golan, Z., Schreiber, L., Wolf, T., Nadler, V., Ben-Tov, A., Kuint, J., Gazit, S., Patalon, T., Chodick, G., and Kishony, R. [2021] Decreased SARS-CoV-2 viral load following vaccination, medRxiv, Cold Spring Harbor Laboratory Press 2021.02.06.21251283.

69. Levine-Tiefenbrun, M., Yelin, I., Katz, R., Herzel, E., Golan, Z., Schreiber, L., Wolf, T., Nadler, V., Ben-Tov, A., Kuint, J., Gazit, S., Patalon, T., Chodick, G., and Kishony, R. [2021] Initial report of decreased SARS-CoV-2 viral load after inoculation with the BNT162b2 vaccine, Nat. Med., Nature Publishing Group 27, 790-792. 
70. Aleman, A., Van Oekelen, O., Upadhyaya, B., Agte, S., Kappes, K., Beach, K., Srivastava, K., Gleason, C. R., PVI study group, Wang, B., Mouhieddine, T. H., Tuballes, K., Geanon, D., Khan, Z., Gonzalez-Reiche, A. S., van Bakel, H., Simons, N. W., Mouskas, K., Charney, A. W., Rahman, A., Kim-Schulze, S., Sordillo, E. M., Krammer, F., Cordon-Cardo, C., Bhardwaj, N., Gnjatic, S., Merad, M., Brown, B. D., Sanchez, L., Chari, A., Jagannath, S., Simon, V., Wajnberg, A., and Parekh, S. [2021] Fatal breakthrough infection after anti-BCMA CAR-T therapy highlights suboptimal immune response to SARS-CoV-2 vaccination in myeloma patients, medRxiv, Cold Spring Harbor Laboratory Press 2021.05.15.21256814.

71. Chen, R. T., and Hibbs, B. [1998] Vaccine Safety: Current and Future Challenges, Pediatric Annals.

72. Halloran, M. E., Haber, M., and Longini, I. M. [1992] Interpretation and Estimation of Vaccine Efficacy under Heterogeneity, Am. J. Epidemiol., Oxford Academic 136, 328-343.

73. A step backwards in the fight against global vaccine inequities, Lancet, Elsevier 397, 23-24.

74. Lythgoe, K. A., Hall, M., Ferretti, L., de Cesare, M., MacIntyre-Cockett, G., Trebes, A., Andersson, M., Otecko, N., Wise, E. L., Moore, N., Lynch, J., Kidd, S., Cortes, N., Mori, M., Williams, R., Vernet, G., Justice, A., Green, A., Nicholls, S. M., Ansari, M. A., Abeler-Dörner, L., Moore, C. E., Peto, T. E. A., Eyre, D. W., Shaw, R., Simmonds, P., Buck, D., Todd, J. A., Oxford Virus Sequencing Analysis Group [OVSG], Connor, T. R., Ashraf, S., da Silva Filipe, A., Shepherd, J., Thomson, E. C., COVID-19 Genomics UK [COG-UK] Consortium, Bonsall, D., Fraser, C., and Golubchik, T. [2021] SARS-CoV-2 within-host diversity and transmission, Science 372.

75. Al Khatib, H. A., Benslimane, F. M., Elbashir, I. E., Coyle, P. V., Al Maslamani, M. A., Al-Khal, A., Al Thani, A. A., and Yassine, H. M. [2020] Within-Host Diversity of SARS-CoV-2 in COVID-19 Patients With Variable Disease Severities, Front. Cell. Infect. Microbiol., Frontiers 0.

76. Singh, U. B., Rophina, M., Chaudhry, R., Senthivel, V., Bala, K., Bhoyar, R. C., Jolly, B., Jamshed, N., Imran, M., Gupta, R., Aggarwal, P., Divakar, M. K., Sinha, S., Arvinden, Bajaj, A., Shamnath, A., Jain, A., COVID CBNAAT CORE GROUP, Scaria, V., Sivasubbu, S., and Guleria, R. [2021, June 3] Variants of Concern responsible for SARS-CoV-2 vaccine breakthrough infections from India.

77. COVID-19 vaccine coverage in health-care workers in England and effectiveness of BNT162b2 mRNA vaccine against infection [SIREN]: a prospective, multicentre, cohort study, Lancet, Elsevier 397, 1725-1735.

78. Abu-Raddad, L. J., Chemaitelly, H., Butt, A. A., and National Study Group for COVID-19 Vaccination. [2021] Effectiveness of the BNT162b2 Covid-19 Vaccine against the B.1.1.7 and B.1.351 Variants, N. Engl. J. Med.

79. Benenson, S., Oster, Y., Cohen, M. J., and Nir-Paz, R. [2021] BNT162b2 mRNA Covid-19 Vaccine Effectiveness among Health Care Workers, N. Engl. J. Med. 384, 1775-1777.

80. Kustin, T., Harel, N., Finkel, U., Perchik, S., Harari, S., Tahor, M., Caspi, I., Levy, R., Leshchinsky, M., Dror, S. K., Bergerzon, G., Gadban, H., Gadban, F., Eliassian, E., Shimron, O., Saleh, L., Ben-Zvi, H., Taraday, E. K., Amichay, D., Ben-Dor, A., Sagas, D., Strauss, M., Avni, Y. S., Huppert, A., Kepten, E., Balicer, R. D., Netzer, D., Ben-Shachar, S., and Stern, A. [2021] Evidence for increased breakthrough rates of SARS-CoV-2 variants of concern in BNT162b2-mRNA-vaccinated individuals, Nat. Med., Nature Publishing Group 1-6.

81. Farinholt, T., Doddapaneni, H., Qin, X., Menon, V., Meng, Q., Metcalf, G., Chao, H., Gingras, M.-C., Farinholt, P., Agrawal, C., Muzny, D. M., Piedra, P. A., Gibbs, R. A., and Petrosino, J. [2021] Transmission event of SARS-CoV-2 Delta variant reveals multiple vaccine breakthrough infections, medRxiv, Cold Spring Harbor Laboratory Press 2021.06.28.21258780.

82. CDC COVID-19 Vaccine Breakthrough Case Investigations Team. [2021] COVID-19 Vaccine Breakthrough Infections Reported to CDC - United States, January 1-April 30, 2021, MMWR Morb. Mortal. Wkly. Rep. 70, 792-793.

83. Duerr, R., Dimartino, D., Marier, C., Zappile, P., Wang, G., Lighter, J., Elbel, B., Troxel, A., and Heguy, A. [2021] Dominance of Alpha and Iota variants in SARS-CoV-2 vaccine breakthrough infections in New York City, medRxiv, Cold Spring Harbor Laboratory Press 2021.07.05.21259547.

84. Ramirez, E., Wilkes, R. P., Carpi, G., Dorman, J., Bowen, C., and Smith, L. [2021] SARS-CoV-2 Breakthrough Infections in Fully Vaccinated Individuals, medRxiv, Cold Spring Harbor Laboratory Press 2021.06.21.21258990.

85. Brinkley-Rubinstein, L., Peterson, M., Martin, R., Chan, P., and Berk, J. [2021] Breakthrough SARS-CoV-2 Infections in Prison after Vaccination, N. Engl. J. Med.

86. Estofolete, C. F., Banho, C. A., Campos, G. R. F., Marques, B. de C., Sacchetto, L., Ullmann, L. S., Possebon, F. S., Machado, L. F., Syrio, J. D., Araújo Junior, J. P., Bittar, C., Rahal, P., Lobo, S. M. A., Ferreira, H. L., Vasilakis, N., and Nogueira, M. L. [2021] Case Study of Two Post Vaccination SARS-CoV-2 Infections with P1 Variants in CoronaVac Vaccinees in Brazil, Viruses, Multidisciplinary Digital Publishing Institute 13, 1237.

87. Rovida, F., Cassaniti, I., Paolucci, S., Percivalle, E., Sarasini, A., Piralla, A., Giardina, F., Sammartino, J. C., Ferrari, A., Bergami, F., Muzzi, A., Novelli, V., Meloni, A., Grugnetti, A. M., Grugnetti, G., Rona, C., Daglio, M., Marena, C., Triarico, 
A., Lilleri, D., and Baldanti, F. [2021] SARS-CoV-2 vaccine breakthrough infections are asymptomatic or mildly symptomatic and are infrequently transmitted, medRxiv, Cold Spring Harbor Laboratory Press 2021.06.29.21259500.

\section{SUPPLEMENTARY DATA}

Supplementary Table 1. Comprehensive tabulation of list of vaccine breakthrough infection reports from various countries across the globe.

\begin{tabular}{|c|c|c|c|c|c|c|}
\hline Country & $\begin{array}{l}\text { No of } \\
\text { breakthroug } \\
\text { h infections }\end{array}$ & $\begin{array}{l}\text { Breakthrou } \\
\text { gh infection } \\
\text { after 1st } \\
\text { dose }\end{array}$ & $\begin{array}{l}\text { Breakthrough } \\
\text { infection } \\
\text { after } 2 \text { nd } \\
\text { dose }\end{array}$ & $\begin{array}{l}\text { Genomic } \\
\text { variants/Line } \\
\text { ages }\end{array}$ & Vaccine & References \\
\hline \multirow[t]{9}{*}{ India } & $677[17$ states] & 85 & 592 & $\begin{array}{l}{[\text { B.1.617.2] }} \\
{[n=384] \text { B.1.1.7 }} \\
{[n=28] . \text { Kappa }} \\
{[B .1 .617 .1]} \\
{[n=22]} \\
\text { B.1.617.3 } \\
{[n=2], \text { and }} \\
\text { Delta AY.2 } \\
{[n=1]}\end{array}$ & $\begin{array}{l}\text { BBV152 or } \\
\text { AZD1222 or } \\
\text { BBIBP-CorV }\end{array}$ & \\
\hline & 495 & - & - & $\begin{array}{l}>90 \% \\
\text { B.1.617.2 }\end{array}$ & $\begin{array}{l}\text { BBV152 or } \\
\text { AZD1222 }\end{array}$ & [56] \\
\hline & 63 & 27 & 36 & $\begin{array}{l}\text { B.1.617.2 and } \\
\text { B.1.1.7 }\end{array}$ & $\begin{array}{l}\text { AZD1222/BB } \\
\text { V152/ }\end{array}$ & {$[76]$} \\
\hline & 6 & - & 6 & $\begin{array}{l}\text { B.1.1.7,B.1.1.,B. } \\
1.1 .306\end{array}$ & $\begin{array}{l}\text { AZD1222/Cov } \\
\text { ishield }\end{array}$ & [12] \\
\hline & 27 & - & - & $\begin{array}{l}\text { B.1.617.1 } \\
{[n=2 ; 8 \%],} \\
\text { B.1.617.2 } \\
{[n=19 ; 76 \%]}\end{array}$ & Not specified & [49] \\
\hline & 36 & - & - & Not Assessed & $\begin{array}{l}\text { BBV152 or } \\
\text { AZD1222 }\end{array}$ & [27] \\
\hline & 679 & - & 679 & Not Assessed & $\begin{array}{l}\text { BBV152 or } \\
\text { AZD1222 }\end{array}$ & {$[24]$} \\
\hline & $19 / 113$ & 1 & 18 & Not Assessed & $\begin{array}{l}\text { AZD1222/BB } \\
\text { V152/ }\end{array}$ & [65] \\
\hline & $48 / 506$ & - & - & Not Assessed & $\begin{array}{l}\text { ChAdOx1 } \\
\text { nCoV-19 }\end{array}$ & {$[26]$} \\
\hline
\end{tabular}




\begin{tabular}{|c|c|c|c|c|c|c|}
\hline UK & 80 & 71 & 9 & Not Assessed & $\begin{array}{l}\text { BNT162b2 } \\
\text { mRNA and } \\
\text { ChAdOx1 } \\
\text { nCOV-19 } \\
\text { adenoviral } \\
\text { vector } \\
\text { vaccines }\end{array}$ & [77] \\
\hline Qatar & 8305 & 6689 & 1616 & $\begin{array}{l}\text { B.1.1.7, } \\
\text { B.1.351 }\end{array}$ & $\begin{array}{l}\text { Pfizer } \\
\text { BNT162b2 }\end{array}$ & [78] \\
\hline \multirow[t]{3}{*}{ Israel } & $\begin{array}{l}366 \\
\text { [Jerusalem] }\end{array}$ & - & - & Not Assessed & BNT162b2 & [79] \\
\hline & $22 / 4,081$ & Not specified & Not specified & Not Assessed & BNT162b2 & [11] \\
\hline & 813 & - & - & $\begin{array}{l}\text { B.1.1.7 and } \\
\text { B.1.351 }\end{array}$ & $\begin{array}{l}\text { BNT162b2 } \\
\text { mRNA vaccine }\end{array}$ & {$[80]$} \\
\hline \multirow[t]{4}{*}{ USA } & 255 [Houston] & - & 255 & $\begin{array}{l}\text { Delta Variant } \\
42[16.5 \%] \\
\text { Others } 213 \\
{[83.5 \%]}\end{array}$ & $\begin{array}{l}\text { BNT162b2 [n } \\
=213,84 \%] \\
\text { Moderna } \\
\text { mRNA-1273 } \\
{[\mathrm{n}=34,13 \%]} \\
\text { or } \\
\text { J\&J/Janssen } \\
\text { JNJ- } \\
78436735[\mathrm{n} \\
=5,2 \%]\end{array}$ & [44] \\
\hline & 6 & Not Specified & Not Specified & B.1.1.7 & $\begin{array}{l}\text { Pfizer } \\
\text { BNT162b2, } \\
\text { Moderna } \\
\text { mRNA-1273, } \\
\text { and Covaxin } \\
\text { BBV152. }\end{array}$ & [81] \\
\hline & $\begin{array}{l}10,262 \text { [46 US } \\
\text { states] }\end{array}$ & Not specified & Not specified & $\begin{array}{l}\text { Sequenced } \\
\text { data available } \\
\text { for } 356 \\
\text { samples alone. } \\
\text { B.1.1.7 [199; } \\
56 \% \text {, B.1.429 } \\
\text { [88; 25\%], } \\
\text { B.1.427 [28; } \\
8 \%], \text { P.1 [28; } \\
8 \%] \text {, and } \\
\text { B.1.351 [13; } \\
4 \%] .\end{array}$ & $\begin{array}{l}\text { FDA-authoriz } \\
\text { ed COVID-19 } \\
\text { vaccine }\end{array}$ & [82] \\
\hline & 24 & - & 24 & $\begin{array}{l}\text { B.1.1.7 }[\mathrm{n}=2] \text {, } \\
\text { P.1 }[\mathrm{n}=1] \text { and } \\
\text { B.1.429 }[\mathrm{n}=2] \\
\text { B.1.1 }[\mathrm{n}=1],\end{array}$ & $\begin{array}{l}\text { BNT162b2 } \\
\text { [Pfizer-BioNT } \\
\text { ech] } 22 \text { [92\%] } \\
\text { mRNA-1273 }\end{array}$ & {$[22]$} \\
\hline
\end{tabular}




\begin{tabular}{|c|c|c|c|c|c|}
\hline & & & $\begin{array}{l}\text { B.1.1.519 [n= } \\
\text { 1], B.1.2 [n = } \\
\text { 2], B.1.243 }\end{array}$ & $\begin{array}{l}\text { [Moderna] } 2 \\
{[8 \%]}\end{array}$ & \\
\hline $\begin{array}{l}20 \\
\text { [Washington] }\end{array}$ & - & 20 & $\begin{array}{l}8[40 \%] \\
\text { B.1.1.7, } 1[5 \%] \\
\text { B.1.351, } 2 \\
{[10 \%] \text { B.1.427, }} \\
8[40 \%] \\
\text { B.1.429, and } 1 \\
{[5 \%]}\end{array}$ & $\begin{array}{l}\text { mRNA-based } \\
\text { mRNA-1273 } \\
\text { and } \\
\text { BNT162b2 }\end{array}$ & [47] \\
\hline 10 [ Florida] & - & 10 & B.1.1.7 & $\begin{array}{l}\text { BNT162b2 } \\
\text { mRNA vaccine }\end{array}$ & {$[50]$} \\
\hline 2 [ New york] & - & 2 & $\begin{array}{l}\text { E484K in } 1 \\
\text { woman and } \\
\text { three } \\
\text { mutations } \\
\text { [T95I, } \\
\text { del142-144, } \\
\text { and D614G] in } \\
\text { both }\end{array}$ & $\begin{array}{l}\text { BNT162b2 } \\
\text { [Pfizer-BioNT } \\
\text { ech] }\end{array}$ & [7] \\
\hline $67[$ New York] & Not Specified & Not specified & $\begin{array}{l}\text { B.1.1.7 [Alpha] } \\
\text { or B.1.526 } \\
\text { [Iota] }\end{array}$ & $\begin{array}{l}\text { BNT162b2 } \\
\text { [Pfizer/BioNT } \\
\text { ech], } \\
\text { mRNA-1273 } \\
\text { [Moderna], or } \\
\text { JNJ-78436735 } \\
\text { [Janssen] }\end{array}$ & [83] \\
\hline $\begin{array}{l}\text { 379[California } \\
\text { ] }\end{array}$ & 342 & 37 & Not Assessed & $\begin{array}{l}\text { mRNA-1273 } \\
\text { vaccine } \\
\text { [Moderna]/ } \\
\text { BNT162b2 } \\
\text { vaccine } \\
\text { [Pfizer] }\end{array}$ & {$[23]$} \\
\hline $\begin{array}{l}8 \text { [152 sites } \\
\text { worldwide } \\
\text { [United States, } \\
130 \text { sites; } \\
\text { Argentina, 1; } \\
\text { Brazil, 2; } \\
\text { South Africa, } \\
\text { 4; Germany, 6; } \\
\text { and Turkey, 9] }\end{array}$ & - & 8 & Not Assessed & BNT162b2 & [14] \\
\hline 22 [Chicago] & - & 22 & Not Assessed & Not specified & [8] \\
\hline
\end{tabular}




\begin{tabular}{|c|c|c|c|c|c|c|}
\hline & $\begin{array}{l}\text { 14[Purdue } \\
\text { University, } \\
\text { ]Indiana }\end{array}$ & Not specified & Not specified & $\begin{array}{l}\text { B.1.1.7[n=4], } \\
\text { P.1[n=2], } \\
\text { B.1.617.2 } \\
{[n=1]}\end{array}$ & $\begin{array}{l}\text { BNT162b2 } \\
\text { [Pfizer/BioNT } \\
\text { ech], } \\
\text { mRNA-1273 } \\
\text { [Moderna], or } \\
\text { JNJ-78436735 } \\
\text { [Janssen] }\end{array}$ & [84] \\
\hline & $\begin{array}{l}27 \\
\text { [RIDOC,Rhode } \\
\text { Island ] }\end{array}$ & 10 & 17 & Not Assessed & $\begin{array}{l}\text { BNT162b2 } \\
\text { [Pfizer-BioNT } \\
\text { ech] or } \\
\text { mRNA-1273 } \\
\text { [Moderna] }\end{array}$ & [85] \\
\hline China & 1 & - & 1 & B.1.1.7 & $\begin{array}{l}\text { Inactivated } \\
\text { COVID-19 } \\
\text { vaccine } \\
\text { [Beijing } \\
\text { Institute of } \\
\text { Biological } \\
\text { Products Co. } \\
\text { LTD] }\end{array}$ & {$[10]$} \\
\hline Indonesia & 1 & - & 1 & $\begin{array}{l}\text { E484K, T951, } \\
\text { del142-144, } \\
\text { and DG14G }\end{array}$ & $\begin{array}{l}\text { CoronaVac } \\
\text { vaccine }\end{array}$ & [53] \\
\hline Brazil & 2 & - & 2 & P.1 & CoronaVac & [86] \\
\hline Italy & 33 & Not specified & Not specified & B.1.1.7 & BNT162b2 & [87] \\
\hline
\end{tabular}

